\title{
Comparing of Employees Motivation Level in Enterprises of Wood Working Industry with other Manufacturing Enterprises in Slovak Republic
}

\section{Razina motiviranosti zaposlenih u poduzećima drvnoprerađivačke industrije u odnosu prema zaposlenima u drugim proizvodnim poduzećima u Slovačkoj}

\author{
Original scientific paper • Izvorni znanstveni rad \\ Received-prispjelo: 19. 1. 2011. \\ Accepted-prihvaćeno: 14. 7. 2011. \\ UDK: $630 * 79$ \\ doi:10.5552/drind.2011.1101
}

\begin{abstract}
This paper is focused on the area of motivation and motivational programs for employees in the wood industry and in other manufacturing enterprises (engineering, food, chemical and textile). The main objective of this paper is to compare the motivation of employees within manufacturing companies of various categories. We analyzed the current state of motivation of employees within manufacturing companies throughout Slovakia. The analysis was made of 21 enterprises with 2576 employees in different job positions. The order of importance was made for 30 selected motivational factors in wood industry and other manufacturing enterprises. The evaluation of statistical correlation between the two compared groups was made by use of the Spearman correlation coefficient, by which statistical dependence was defined between the category of workers and the category of technical-economic employees. The results show fundamental difference of the importance of motivational factors within technical and marketing staff of woodworking companies and other manufacturing companies. In the category of workers, diversity of the importance of motivational factors is less significant. Our analysis showed that in a long period of time all employees keep their motivation at a constant level.
\end{abstract}

Key words: Employee motivation, motivational program, methods of motivation analysis

SAŽETAK・Radje usmjeren na motivaciju i motivacijske programe zaposlenika u drvnoj industriji i drugim proizvodnim poduzéima (strojogradnji, proizvodnji hrane, kemijskoj i tekstilnoj industriji). Osnovni cilj rada bio je us-

\footnotetext{
${ }^{1}$ Authors are associate professor and assistant at Faculty of Wood Science and Technology, Technical University of Zvolen, Zvolen, Slovakia.

Autori su izvanredni profesor i asistentica Fakulteta znanosti o drvu i drvne tehnologije Tehničkog sveučilišta u Zvolenu, Zvolen, Slovačka.
} 
porediti motiviranost zaposlenika u različitim proizvodnim poduzećima. Analizirano je trenutačno stanje motiviranosti zaposlenika u više proizvodnih poduzeća na području Slovačke. Istraživanjem je obuhvaćeno 21 poduzeće s ukupno 2576 zaposlenika na različitim radnim mjestima. Za 30 odabranih motivacijskih činitelja određen je redoslijed važnosti u drvnoprerađivačkoj industriji i drugim proizvodnim poduzećima. Ocjena statističke povezanosti dviju uspoređenih skupina poduzeća napravljena je primjenom Spearmanova koeficijenta korelacije za dvije skupine zaposlenika - skupinu radnika i skupinu tehničko-ekonomskog osoblja. Rezultati su pokazali bitnu razliku glede motivacijskih činitelja važnih za tehničko-ekonomsko osoblje drvnoindustrijskih poduzeća u odnosu prema drugim proizvodnim poduzećima. U skupini radnika, različitost važnosti motivacijskih činitelja manje je naglašena. Na temelju dobivenih rezultata i promatrajući dulje razdoblje, može se zaključiti da radnici zadržavaju jednaku razinu motiviranosti.

\section{Ključne riječi: motiviranost zaposlenika, motivacijski program, metoda analize motivacije}

\section{INTRODUCTION}

\section{UVOD}

The existence of the enterprise, its prosperity and dynamic progress are primarily affected by the quality of human resources. Prosperous enterprises realize that the most profitable capital of the enterprise is its employees and their motivation, through which an enterprise can successfully meet its objectives. All organizations are interested in the options, ways and means that could improve the quality of its employees. This effort can only give good results on the basis of systemically conceived management of human resources, which represents coherent and comprehensive approach to ensuring a mutually supportive policy and practice of employing people.

The uniqueness of human resources, as the contributor of all values, requires that the potential of all employees be used judiciously and developed so as to continue to bring new value. Effective functioning and development of employees requires systematic evaluation and motivation and related evaluation and motivational processes. Programs are mostly used that represent specific definition of the system for dealing with people in an enterprise with a relatively strong focus on positive impact on the work performance of employees (Zámečník, 1999).

As motivating employees is highly impacted by different motivational factors, the manner in which individual managers try to motivate individual employees, teams and organizations is different. Some of them are focused on the rationality and orderliness, others require from employees to handle more difficult processes and some others use self-realization as a basic human need. At present, motivation process in most manufacturing enterprises does not cover all their needs. Business environment and its existence are largely dependent on the use of all business activities. Motivation will be required in every area of business activity for achieving the important objectives. Most businesses, however, have only unified motivational programs for all levels of their employees.

\subsection{Actual situation of employee motivation in} manufacturing enterprises

1.1. Aktualna situacija motiviranosti zaposlenika u proizvodnim poduzećima

Surveys of motivational structure of employees should accept the general understanding of motivation theory (the theory of needs, attitudes expected) and should be one of the first gradual steps in developing a motivational program in an organization. Together with other methods of psychological and sociological surveys, it allows to evaluate motivational effects. Without this basic knowledge, the construction and implementation of the proposed measures are only accidental processes (Potkány, 2004).

Work performance is affected by a number of factors. Some have a significant impact on the level of motivation, others have less impact. The effect of many factors is of contingent nature depending on the environment and work situations in which they apply. In terms of motivating performance, some of the most important factors are rewards and sanctions, which mainly mobilize human behavior. Speaking of rewards, people usually think of money. It should be noted, however, that although money is an important factor, it has the strongest effect, as a rule, only the first month. Then the enterprise must focus on other factors leading to the motivation of employees.

At the beginning of this research, we assumed that the work motivation factors (money, physical environment, work content, work team, level and style of management, job satisfaction, personality and leadership and identification with the work) would be dominant for achieving good work results, and that employees would be motivated in the process of Maslow's hierarchy of needs. After completing the analysis and summarizing the results, we can conclude that there is a high diversity of assumptions regarding motivational factors, the actually used motivational factors in businesses and the actual requirements of the analyzed groups of employees. The objective of our work is to confirm the hypothesis of the importance of financial motivation factors and job security as the dominant motivating factors in all categories of employees in woodworking, as well as other manufacturing companies.

\section{MATERIAL AND METHODS} 2. MATERIJAL I METODE

Motivational programs (both individual and group) are often used in enterprises as a part of adaptation programs to keep employees' performance at the required level. The motivational program must be tailored to corporate culture and enterprise opportunities 
(Růžička and Dražská, 1992). In our organizations, motivational programs are elaborated in detail only exceptionally. Their execution and incorporation into enterprise internal documents is expected to change total access to the role of employees in the enterprise. It would be ideal to create a motivational program tailored to each employee, and however this would be economically unfeasible and time demanding. On the other hand, production of surface motivational programs may miss action because of differences in motivational orientation of individual employees. In many cases there are small differences in the motivational profile of employees who may have a significant impact on the overall performance. In our work, on the basis of past experience and by scientific and statistical methods, we tried to design a model that can be used in enterprises with similar motivation-oriented group of employees.

First of all, analysis was made of enterprises of wood production in first-stage and then also in second stage processing of raw wood material in the region of Central Slovakia. Then we analyzed manufacturing enterprises with other business objects, e.g. mechanical engineering, food, chemicals and textile. We have also used the questionnaire method, which allows collecting in a short time large quantity of information. The questionnaire is one of the specific methods used in social sciences. It is the method for collecting data by posing questions to people. It is suitable for the mass data collection for statistical processing. This makes it possible to capture all views, positions, interests, etc. The basic condition for an effective questionnaire is the exact presentation of the goal and tasks of the questionnaire in relation to the selected problem. It is a relatively quick and easy method. Compared with other analytical methods it has many advantages. One of the best advantages is that respondents are open and relaxed in expressing their opinion as questionnaires are anonymous. Compared to a personal interview, the questionnaire is less stressful and the answers are not largely influenced by the atmosphere and environment. By using a questionnaire, it is also possible to analyze basic information about respondents, such as age, years of work experience, education and so on.

Another method for comparing the motivation levels is the cluster analysis. Given that the system of employee motivation is based on a distribution of criteria into disjunctive groups according to homogenous characteristics, the final assessment of the employee groups use cluster analysis (CLUA), where by the use of appropriate algorithms, we can work towards the creation of different groups to which individual employees can be included (Anděl, 1985). Cluster analysis can be used to explore the possibility of creating types of motivational programs, and it can also provide the possibility of drawing up unified motivation programs for groups of managers with similar motivation profile. The objective of the analysis is to detect whether, based on measurement of similarity of respondent responses to the questionnaire, groups of employees can be distinguished with a similar motivational factor. This could be the basis for elaborating uniformity of motivational programs aimed at simplifying and making more effective the application of motivational schemes in practice. Furthermore, cluster analysis can also be used to further verify the structure and order importance of motivation criteria. A large number of clustering techniques recommend the use of hierarchical clustering method called Ward method for measuring the degree of similarity of answers of individual respondents in the simplest way, using the socalled Euclidean distance.

Analysis was made of a total of 21 enterprises with 2576 employees of different job positions. 30 selected motivational factors were ranked according to their importance within wood-working enterprises and other manufacturing enterprises. We explored the statistical dependence between the two orders in the category of workers and technical-economic employees. As in our case there are no quantitative data, but only qualitative ones, to assess the statistical significance of correlation between the two compared groups, we have used the Spearman correlation coefficient, which is often used as serial correlation coefficient in assessing the statistical dependence of data quality. Ranking was made of dimensions $X_{1}, \ldots, X_{n}$ (ranking of motivational factors of wood enterprises) and dimensions $Y_{1}, \ldots, Y_{n}$ (ranking of motivational factors of other production enterprises). In testing the hypothesis that $X_{i}$ and $Y_{i}$ are independent random dimensions $(i=1,2, \ldots, n)$ dimensions $X_{1}, \ldots, X_{n}$ were ordered by size and their sequence $Q_{1}, \ldots, Q_{n}$ was established. Spearman correlation coefficient (Lohninger, 1999) was then calculated as follows: (1)

$$
r_{s}=1-\frac{6}{n\left(n^{2}-1\right)} \sum_{i=1}^{n}\left(R_{i}-Q_{i}\right)^{2}
$$

Where:

$r_{s}$ - Spearman correlation coefficient

$n$ - number of variables (in our case 30 )

$R_{i}$ - order dimensions $X$

$Q_{i}$ - order dimensions $Y$

Subsequently in the tables of critical values (Anděl, 1985, s. 234) 5\% critical value of Spearman's correlation coefficient for $n=30$ (n is the number of motivational factors) is the value of 0.362 and $1 \%$ critical value of 0.467 . In the case of workers, the calculated correlation coefficient was $r_{\mathrm{s}}=0.813$ (Table 4), which means that the importance of motivational factors in workers of woodworking enterprises is pretty identical to the importance of motivational factors of workers in other manufacturing enterprises. In case of technical-economic employees the correlation coefficient was $r_{\mathrm{s}}=0.497$ (Table 3), which means that technical-economic employees in wood-working enterprises also prefer the same motivational factors as technical-economic employees in other manufacturing enterprises, but the match is not as good as in workers. This can be explained by the fact that workers are not so heavily involved in the production and economic results of enterprises as technical-economic employees. On the other hand, technical-economic employees are 
aware of a specific wood production over other manufacturing enterprises.

\section{RESULTS AND DISCUSSION 3. REZULTATI I RASPRAVA}

At present, in most companies, not enough attention is paid to motivation of employees, although it is a powerful tool to increase performance and productivity. Many enterprises have a way to motivate employees individually, mostly by financial motivating factors, different forms of social care, education and employee benefits. Other enterprises find other ways to motivate employees.

Modern personnel work and modern human resources management have not been for long only a matter of personnel managers, and the tasks of personnel management are more and more assumed by managers at various levels, especially by the line managers. Managers at all levels are the final point where that practical personnel work implements corporate personnel policy. For this reason it must be provided with thorough theoretical and practical knowledge. It is necessary to understand the importance, status and wide personnel mana-

Table 1 Order scores of motivational factors of workers and technical-economic employees of wood-working and other enterprises

Tablica 1. Bodovi na ljestvici motivacijskih činitelja radnika i tehničko-ekonomskog osoblja zaposlenih u drvnoprerađivačkoj industriji i u drugim proizvodnim poduzećima

\begin{tabular}{|c|c|c|c|c|c|}
\hline \multirow[b]{2}{*}{$\begin{array}{l}\text { Nos. } \\
\text { R.br. }\end{array}$} & \multirow[b]{2}{*}{$\begin{array}{l}\text { Motivational factor } \\
\text { Motivacijski činitelj }\end{array}$} & \multicolumn{4}{|c|}{$\begin{array}{l}\text { Sequence scores of motivational } \\
\text { factors / Bodovi na ljestvici } \\
\text { motivacijskih činitelja }\end{array}$} \\
\hline & & 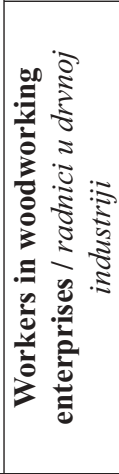 & 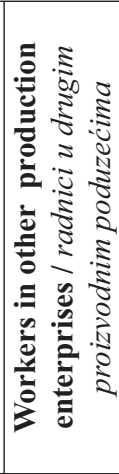 & 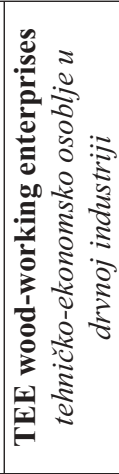 & 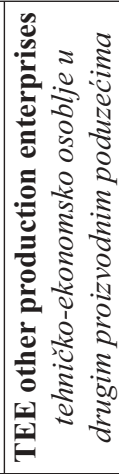 \\
\hline 1 & Workplace atmosphere / atmosfera na radnome mjestu & 67 & 45 & 98 & 19 \\
\hline 2 & Workplace safety /sigurnost na radnome mjestu & 38 & 50 & 49 & 27 \\
\hline 3 & Another monetary reward / druga novčana naknada & 72 & 48 & 28 & 44 \\
\hline 4 & Good work team / dobar radni tim & 60 & 68 & 91 & 21 \\
\hline 5 & Physical work demands / fizički radni zahtjevi & 7 & 14 & 0 & 17 \\
\hline 6 & Certainty of job / sigurnost posla & 83 & 49 & 63 & 45 \\
\hline 7 & Workplace communication / komunikacija na radnomemjestu & 25 & 44 & 39 & 32 \\
\hline 8 & Company name / naziv kompanije & 27 & 28 & 53 & 60 \\
\hline 9 & Possibility of applying own skills /mogućnost primjene vlastitih vještina & 15 & 0 & 56 & 16 \\
\hline 10 & Performance and type of work / ispunjenje i vrsta posla & 10 & 17 & 7 & 39 \\
\hline 11 & Familiarity with working results achieved / upoznatost s postignutim rezultatima & 8 & 36 & 18 & 19 \\
\hline 12 & Working hours / radno vrijeme & 25 & 44 & 0 & 41 \\
\hline 13 & Working environment / radno okruženje & 15 & 18 & 14 & 15 \\
\hline 14 & Working process / radni proces & 20 & 20 & 14 & 25 \\
\hline 15 & Work achievement / radna postignuća & 20 & 38 & 11 & 46 \\
\hline 16 & Competence / kompetentnost & 12 & 38 & 18 & 17 \\
\hline 17 & Prestige / prestiž & 0 & 0 & 0 & 0 \\
\hline 18 & Access to superiors / pristup nadredenima & 52 & 40 & 74 & 43 \\
\hline 19 & Psychological stress / psihološki stres & 0 & 0 & 4 & 0 \\
\hline 20 & Independent decision-making / neovisnost u donošenju odluka & 17 & 31 & 32 & 33 \\
\hline 21 & Self-realization / samorealizacija & 0 & 0 & 0 & 15 \\
\hline 22 & Social benefits / društvene povlastice & 35 & 28 & 11 & 6 \\
\hline 23 & Fair evaluation of employee / poštena ocjena zaposlenika & 57 & 25 & 7 & 36 \\
\hline 24 & Recognition / priznanje & 12 & 6 & 0 & 3 \\
\hline 25 & Company vision / vizija poduzeća & 5 & 10 & 0 & 16 \\
\hline 26 & Leisure / slobodno vrijeme & 50 & 28 & 21 & 32 \\
\hline 27 & Development region / područje razvoja & 7 & 0 & 0 & 7 \\
\hline 28 & Learning and personal growth / učenje i osobni razvoj & 0 & 2 & 7 & 9 \\
\hline 29 & Business relationship to environment / poslovni odnos prema ekologiji & 0 & 25 & 0 & 31 \\
\hline 30 & Basic salary / osnovna plaća & 88 & 73 & 60 & 56 \\
\hline
\end{tabular}


gement in relation with other areas of corporate governance. Current business environment and its existence are largely dependent on the use of all business activities, which are able to maintain the required market share while achieving the planned profit.

In the process of evaluation of sequence scores of motivational factors for workers it can be seen that there are more motivational factors, but their significance and importance between wood-working and other enterprises is however less different. In both types there are 2 main areas - financial (base salary and other monetary reward) and work (workplace atmosphere, good work team, access to supervisors). The evaluation of sequence scores of technical-economic employees shows big difference of significance and preferences of individual motivational factors.

To compare the importance of motivational factors in individual categories (technical-economic employees and workers), T-test was performed. It can be concluded from the results that the motivation profile of technicaleconomic employees in wood-working enterprises is based on relatively much less important factors (according to technical-economic employees many motivational factors were of little importance). Less important factors are less frequent and there are four factors (workplace atmosphere, good work team, access to superiors, certainty of job) consistently considered as highly important (see Table 2 and Figure 2).

Table 2 Comparison of sequence scores of motivational factors of technical-economic employees

Tablica 2. Usporedba poretka bodova motivacijskih činitelja za tehničko-ekonomsko osoblje

\begin{tabular}{|c|c|c|c|c|}
\hline \multirow[t]{2}{*}{$\begin{array}{l}\text { Technical-economic employees } \\
\text { Tehničko-ekonomsko osoblje }\end{array}$} & $\begin{array}{c}\text { Other manufacturing } \\
\text { enterprises } \\
\text { Druga proizvodna } \\
\text { poduzeća }\end{array}$ & \begin{tabular}{|c|} 
Wood-working \\
enterprises \\
Drvnoprerađiva- \\
čka poduzeća \\
\end{tabular} & & \\
\hline & $R_{i}$ & $Q_{i}$ & $R_{i}-Q_{i}$ & $\left(R_{i}-Q_{i}\right)^{2}$ \\
\hline Workplace atmosphere / atmosfera na radnome mjestu & 13.5 & 30 & -16.5 & 272.25 \\
\hline Workplace safety / sigurnost na radnome mjestu & 17 & 23 & -6 & 36.00 \\
\hline Another monetary reward / druga novčana naknada & 26 & 20 & 6 & 36.00 \\
\hline Good work team / dobar radni tim & 15 & 29 & -14 & 196.00 \\
\hline Physical work demands / fizički radni zahtjevi & 11.5 & 4.5 & 7 & 49.00 \\
\hline Certainty of job / sigurnost posla & 27 & 27 & 0 & 0.00 \\
\hline $\begin{array}{l}\text { Workplace communication } \\
\text { komunikacija na radnome mjestu }\end{array}$ & 19.5 & 22 & -2.5 & 6.25 \\
\hline Company name / naziv kompanije & 30 & 24 & 6 & 36.00 \\
\hline $\begin{array}{l}\text { Possibility of applying own skills } \\
\text { mogućnost primjene vlastitih vještina }\end{array}$ & 9.5 & 25 & -15.5 & 240.25 \\
\hline Performance and type of work / ispunjenje i vrsta posla & 23 & 11 & 12 & 144.00 \\
\hline $\begin{array}{l}\text { Familiarity with working results achieved } \\
\text { upoznatost s postignutim rezultatima }\end{array}$ & 13.5 & 17.5 & -4 & 16.00 \\
\hline Working hours / radno vrijeme & 24 & 4.5 & 19.5 & 380.25 \\
\hline Working environment / radno okruženje & 7.5 & 15.5 & -8 & 64.00 \\
\hline Working process / radni proces & 16 & 15.5 & 0.5 & 0.25 \\
\hline Work achievement / radna postignuća & 28 & 13.5 & 14.5 & 210.25 \\
\hline Competence / kompetentnost & 11.5 & 17.5 & -6 & 36.00 \\
\hline Prestige / prestiž & 1.5 & 4.5 & -3 & 9.00 \\
\hline Access to superiors / pristup nadređenima & 25 & 28 & -3 & 9.00 \\
\hline Psychological stress / psihološki stres & 1.5 & 9 & -7.5 & 56.25 \\
\hline $\begin{array}{l}\text { Independent decision-making } \\
\text { neovisnost } u \text { donošenju odluka }\end{array}$ & 21 & 21 & 0 & 0.00 \\
\hline Self-realization / samorealizacija & 7.5 & 4.5 & 3 & 9.00 \\
\hline Social benefits / društvene povlastice & 4 & 13.5 & -9.5 & 90.25 \\
\hline $\begin{array}{l}\text { Fair evaluation of employee } \\
\text { poštena ocjena zaposlenika }\end{array}$ & 22 & 11 & 11 & 121.00 \\
\hline Recognition / priznanje & 3 & 4.5 & -1.5 & 2.250 \\
\hline Company vision / vizija poduzeća & 9.5 & 4.5 & 5 & 25.00 \\
\hline Leisure / slobodno vrijeme & 19.5 & 19 & 0.5 & 0.25 \\
\hline Development region / područje razvoja & 5 & 4.5 & 0.5 & 0.25 \\
\hline Learning and personal growth / učenje i osobni razvoj & 6 & 11 & -5 & 25.00 \\
\hline $\begin{array}{l}\text { Business relationship to environment } \\
\text { poslovni odnos prema ekologiji }\end{array}$ & 18 & 4.5 & 13.5 & 182.25 \\
\hline Basic salary / osnovna plaća & 29 & 26 & 3 & 9.00 \\
\hline & & & $\sum_{i=1}^{n}\left(R_{i}-Q_{i}\right)^{2}$ & 2261 \\
\hline & & & $r_{\mathrm{s}}$ & 0.497 \\
\hline
\end{tabular}




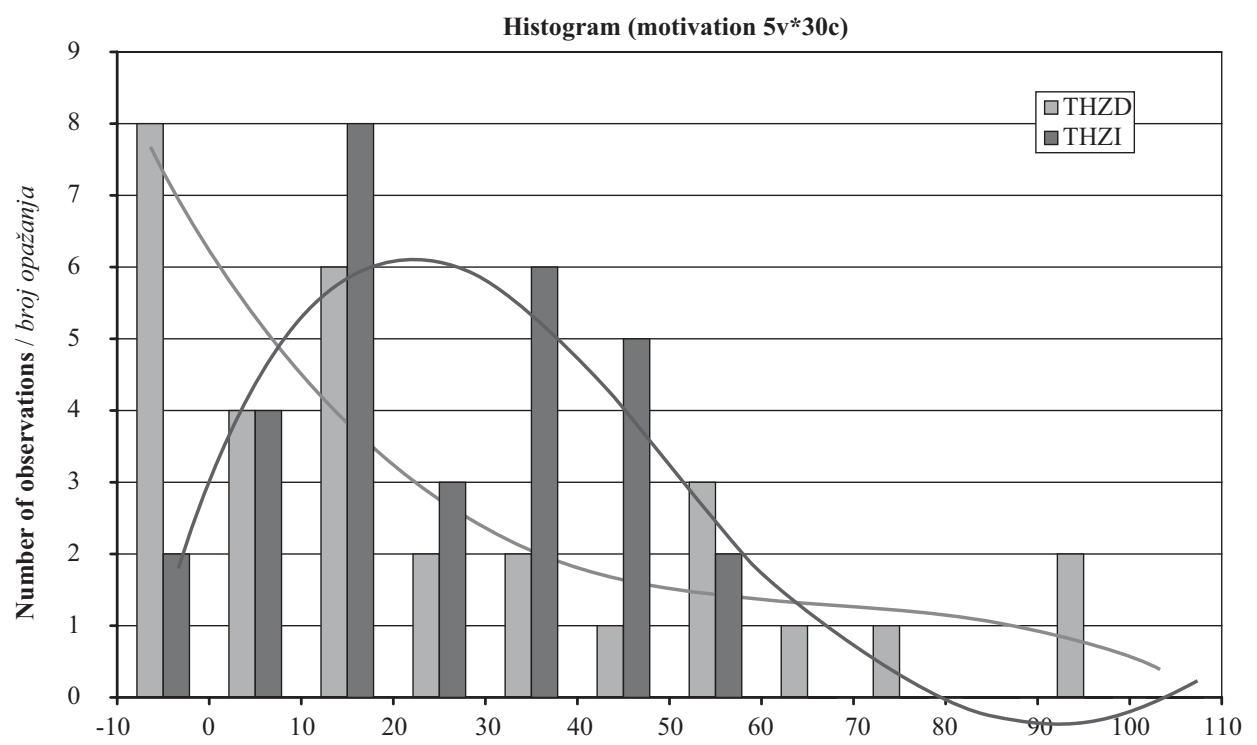

Figure 1 Histogram comparing motivation of technical employees in wood processing (THZD) and other companies (THZI) Slika 1. Histogram usporedbe motiviranosti tehničko-ekonomskog osoblja u drvno-prerađivačkim poduzećima (THZD) i drugim proizvodnim poduzećima (THZI)

For workers, the situation is similar, but differrences in the frequency of occurrence of important motivational factors are smaller and generally more similar to the $\mathrm{TH}$ staff in woodworking business. The difference is seen in the fact that for workers in other enterprises the frequency of a few important factors was higher, and it was approximately the same as the frequency of the group of moderate factors and higher than the frequency of factor 2-3, rated as very important. Unlike other businesses, TH staff named two dominant motivational factors - job security and the basic salary (see Table 3 and Figure 2).

\section{CONCLUSION 4. ZAKLJUČAK}

The most important prerequisite for a long employment is satisfaction at work and employee willingness to understand the fact that the work performed is meaningful and significant for the enterprise, interesting, appropriately challenging and providing opportunities for personal development. If employees have prospects and specific opportunities for professional development and promotions based on the evaluation of the quantity and quality of work performed, a long

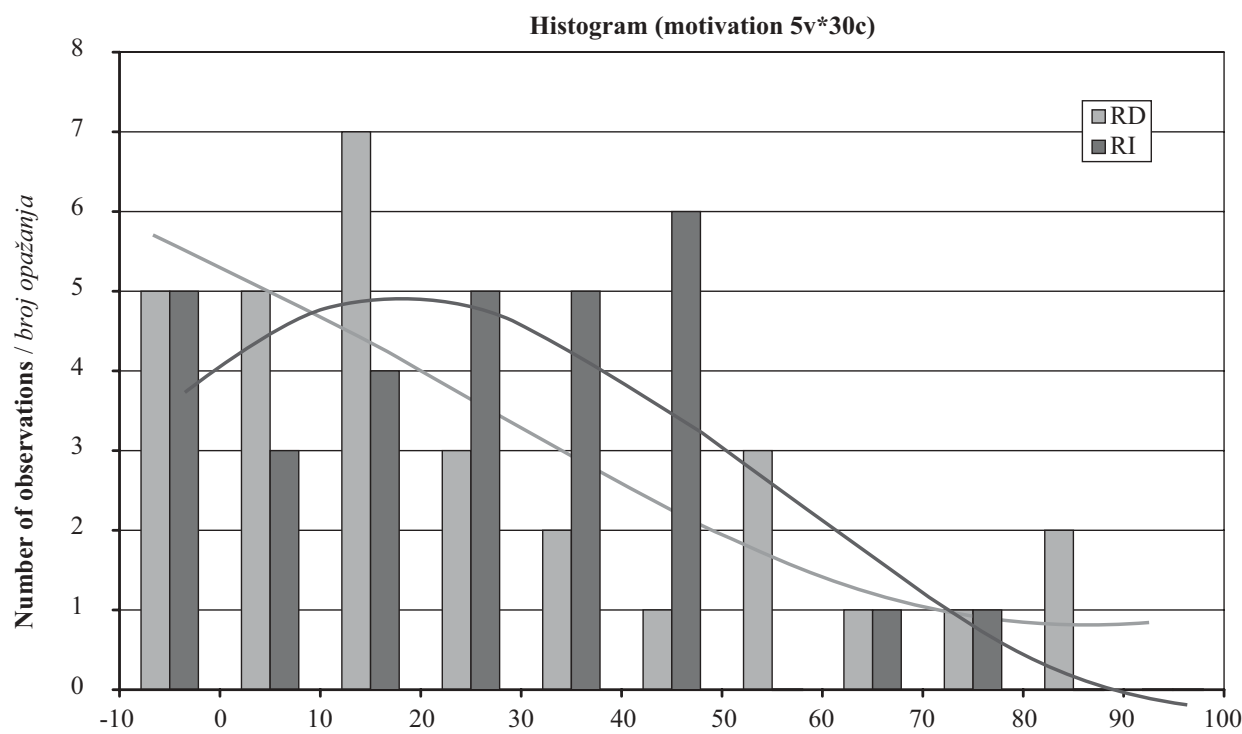

Figure 2 Histogram comparing motivation of workers in wood processing (RD) and other companies (RI) Slika 2. Histogram usporedbe motiviranosti radnika u drvnoprerađivačkim poduzećima $(R D)$ i drugim proizvodnim poduzećima (RI) 
Table 3 Comparison of sequence scores of motivational factors of workers

Tablica 3. Usporedba poretka bodova motivacijskih činitelja za radnike

\begin{tabular}{|c|c|c|c|c|}
\hline \multirow[t]{2}{*}{ Workers / Radnici } & $\begin{array}{c}\text { Other manufac- } \\
\text { turing enterprises } \\
\text { Druga proizvodna } \\
\text { poduzeća }\end{array}$ & $\begin{array}{l}\text { Wood-working } \\
\text { enterprises } \\
\text { Drvnoprerađi- } \\
\text { vačka poduzeća }\end{array}$ & & \\
\hline & $R_{i}$ & $Q_{i}$ & $R_{i}-Q_{i}$ & $\left(R_{i}-Q_{i}\right)^{2}$ \\
\hline Workplace atmosphere / atmosfera na radnome mjestu & 25 & 27 & -2 & 4.00 \\
\hline Workplace safety / sigurnost na radnome mjestu & 28 & 22 & 6 & 36.00 \\
\hline Another monetary reward / druga novčana naknada & 26 & 28 & -2 & 4.00 \\
\hline Good work team / Dobar radni tim & 29 & 26 & 3 & 9.00 \\
\hline Physical work demands / fizički radni zahtjevi & 9 & 7.5 & 1.5 & 2.25 \\
\hline Certainty of job / sigurnost posla & 27 & 29 & -2 & 4.00 \\
\hline $\begin{array}{l}\text { Workplace communication } \\
\text { komunikacija na radnome mjestu }\end{array}$ & 23.5 & 18.5 & 5 & 25.00 \\
\hline Company name / naziv kompanije & 16 & 20 & -4 & 16.00 \\
\hline $\begin{array}{l}\text { Possibility of applying own skills } \\
\text { mogućnost primjene vlastitih vještina }\end{array}$ & 3 & 13.5 & -10.5 & 110.25 \\
\hline Performance and type of work / ispunjenje i vrsta posla & 10 & 10 & 0 & 0.00 \\
\hline $\begin{array}{l}\text { Familiarity with working results achieved } \\
\text { upoznatost s postignutim rezultatima }\end{array}$ & 19 & 9 & 10 & 100.00 \\
\hline Working hours / radno vrijeme & 23.5 & 18.5 & 5 & 25.00 \\
\hline Working environment / radno okruženje & 11 & 13.5 & -2.5 & 6.25 \\
\hline Working process / radni proces & 12 & 16.5 & -4.5 & 20.25 \\
\hline Work achievement / radna postignuća & 20.5 & 16.5 & 4 & 16.00 \\
\hline Competence / kompetentnost & 20.5 & 11.5 & 9 & 81.00 \\
\hline Prestige / prestiž & 3 & 3 & 0 & 0.00 \\
\hline Access to superiors / pristup nadređenima & 22 & 24 & -2 & 4.00 \\
\hline Psychological stress / psihološki stres & 3 & 3 & 0 & 0.00 \\
\hline $\begin{array}{l}\text { Independent decision-making } \\
\text { neovisnost } u \text { donošenju odluka }\end{array}$ & 18 & 15 & 3 & 9.00 \\
\hline Self-realization / samorealizacija & 3 & 3 & 0 & 0.00 \\
\hline Social benefits / društvene povlastice & 16 & 21 & -5 & 25.00 \\
\hline Fair evaluation of employee / poštena ocjena zaposlenika & 13.5 & 25 & -11.5 & 132.25 \\
\hline Recognition / priznanje & 7 & 11.5 & -4.5 & 20.25 \\
\hline Company vision / vizija poduzeća & 8 & 6 & 2 & 4.00 \\
\hline Leisure / slobodno vrijeme & 16 & 23 & -7 & 49.00 \\
\hline Development region / područje razvoja & 3 & 7.5 & -4.5 & 20.25 \\
\hline Learning and personal growth / učenje i osobni razvoj & 6 & 3 & 3 & 9.00 \\
\hline $\begin{array}{l}\text { Business relationship to environment } \\
\text { poslovni odnos prema ekologiji }\end{array}$ & 13.5 & 3 & 10.5 & 110.25 \\
\hline Basic salary / osnovna plaća & 30 & 30 & 0 & 0.00 \\
\hline & & & $\sum_{i=1}^{n}\left(R_{i}-Q_{i}\right)^{2}$ & 842 \\
\hline & & & $r_{\mathrm{s}}$ & 0.813 \\
\hline
\end{tabular}

employment and good job performance can be expected from them. To maintain this situation, it is necessary to keep staff motivated. Since the development of motivation may be variable sometimes, it is necessary to keep the motivational needs of employees, to analyze them and, where appropriate, to introduce incentive programs to update the organization.

Analysis was carried out of motivational factors of workers that matched in a certain number of motivational factors for different groups of employees. The importance of motivational factors was then compared in each category (white-collar employees and workers). It can be concluded from the results that the technical-economic employees of woodworking enterprises have many factors with a relatively marginal importance, fewer medium significance factors and 4 highly relevant factors (workplace atmosphere, good work team, access to managers, job security). The technical-economic employees of other companies have underperforming factors with major and minor importance (most of the factors considered moderately important). An incentive program designed with the emphasis on a wider range of motivational factors would be more favorable for them. The workers showed smaller differences in the frequency of occurrence according to the importance of motivational factors. The difference is the increasing frequency of a few important factors, which has approximately the same frequency as a group of moderate factors and 
factors 2-3 rated as very important. In our analysis, it should be noted that in the long run staff should maintain their motivational needs. Based on the analysis of the company Slovak Power Plant, it can be concluded that a fundamental change in motivation occurred after five years in all job categories. This period may not be the same for other businesses. Based on experience, regular analysis of motivation is recommended in one year interval. For the sake of objectivity, analysis of motivational factors should be carried out systematically and the results obtained should be compared with the prospects of the enterprise performance and business objectives. Economic factors should be monitored for a long period of time (2-6 years), as well as the overall economic and social situation.

At the beginning of the research, we assumed that the reported motivation factors (financial motivational factors and job security) would be dominant for achieving good work results and that employees would be motivated in the process of Maslow's hierarchy of needs. After completing the analysis and summarizing the results, we can conclude that there is a high diversity of assumptions regarding motivational factors, the actually used motivational factors in businesses and the actual requirements of the analyzed groups of employees. The main difference is seen in the way of motivating the TH employees, where the dominant factors are the workplace atmosphere, good work team and access to superiors. The factor of job security has been clearly confirmed by our research. In the category of workers, the two main motivation factors are job security and the basic salary, which clearly confirmed our assumptions that these motivation factors should be used in enterprises to maintain the required performance of employees.
Finally, it is necessary to emphasize the need for continuous updating of incentive programs in accordance with the development of value orientated staff, which may vary, and to recommend the possibility of individualisation of the general incentive program with motivational factors related to self-realization and personal ambitions of individual employees or groups.

\section{REFERENCES}

\section{LITERATURA}

1. Anděl, J. 1985. Matematická statistika. SNTL Alfa, Praha 1985.

2. Lohninger, H. 1999. Teach/Me Data Analysis. Single User Edition. Springer Verlag Berlin Heidelberg New York. 1999.

3. Potkány, M. 2004. Uplatnenie controllingu vo vnútropodnikovom riadení, personálnom manažmente a manažérstve kvality podnikov DSP. In: Vedecká štúdia 7/2004/B, Zvolen: TU vo Zvolene, 2004, pp. 92 s.

4. Růžička, J., Dražská, E. 1992. Motivace pracovního jednání. VŠE, Praha 1992.

5. Zámečník, R. 1999. Motivační program podniku jako základ účinné stimulace pracovníků. Medzinárodná konferencia 50 rokov vysokoškolského drevárskeho štúdia. TU Zvolen, 27.-28.9.1999, 72-79.

\section{Corresponding address:}

Assoc. Prof. MILOŠ HITKA, Ph.D.

Department of Enterprise Management

Faculty of Wood Science and Technology

Technical University in Zvolen

T.G. Masaryka 24

96053 Zvolen, SLOVAKIA

e-mail: hitka@vsld.tuzvo.sk 